Cal ci toni $n$ - I i ke subst ance in pl asma of the hagf i sh, Ept at r et us burger i ( Cycl ost omat a).

\begin{tabular}{|l|l|}
\hline 著者 & Suzuki Nobuo \\
\hline $\begin{array}{l}\text { j our nal or } \\
\text { publ i cat i on ti t l e }\end{array}$ & Zool ogi cal sci ence \\
\hline vol une & 12 \\
\hline number & 5 \\
\hline page r ange & $607-610$ \\
\hline year & $1995-10-01$ \\
\hline URL & ht t p: //hdl . handl e. net /2297/10562 \\
\hline
\end{tabular}




\title{
Calcitonin-like Substance in Plasma of the Hagfish, Eptatretus burgeri (Cyclostomata)
}

\author{
NoBuo SuzuKI \\ Noto Marine Laboratory, Kanazawa University, Ogi, \\ Uchiura, Ishikawa 927-05, Japan
}

\begin{abstract}
Cyclostomes have been regarded as having no ultimobranchial gland. However, cells producing immunoreactive calcitonin (CT) were recently found in cyclostome brains. In the present study, we examined using biochemical and biological methods whether there is a CT-like substance in the plasma of the hagfish, Eptatretus burgeri. Hagfish plasma was first subjected to reverse-phase high-performance liquid chromatography (RP-HPLC) and then separated into twenty fractions. The presence of immunoreactive CT in each fraction was then investigated by Western blotting with salmon CT antiserum. Two fractions $\left(36-39 \% \mathrm{CH}_{3} \mathrm{CN} ; 39-42 \% \mathrm{CH}_{3} \mathrm{CN}\right)$ showed positive immunoreactivity. Hypocalcemic and hypophosphatemic activities were detected by a rat bioassay only in the former fraction (36-39\% $\left.\mathrm{CH}_{3} \mathrm{CN}\right)$. The molecular weight $(\mathrm{MW})$ of the CT-like substance in this fraction was $3.5 \mathrm{kDa}$, which is equal to that of genuine CT. Furthermore, when hagfish plasma was examined by enzyme-linked immunosorbent assay using antisalmon CT, the dilution curve of the plasma paralleled the standard curve of salmon CT. The CT-like substance detected here was present at a high concentration $(14 \mathrm{ng} / \mathrm{ml})$ in the plasma. From the results of the present study, the CT-like substance present in hagfish plasma appears to be very similar to salmon CT.
\end{abstract}

\section{INTRODUCTION}

Calcitonin (CT) is a 32 amino acid peptide hormone which functions to suppress osteoclastic resorption of bones followed by decreases in serum $\mathrm{Ca}$ level in mammals [8]. This hormone is secreted from $\mathrm{C}$-cells of the thyroid gland in mammals and from the ultimobranchial gland (UBG) in non-mammalian vertebrates [2].

Watzka [16] reported from morphological observations that there is no UBG in cyclostomes. Administration of the extract from the branchial region of hagfish to rats did not induce significant hypocalcemia [2]. It has been concluded that there is no UBG in Cyclostoma, as judged from the results of morphological observations and pharmacological studies. On the other hand, CT immunoreactivity was found in the brain of one species of hagfish by radioimmunoassay using human $C T$ antiserum [4]. Immunoreactive CT-positive cells were also detected in the brain of two species of hagfish and two species of lamprey by an immunohistological method using salmon CT antiserum [11]. It is possible that these cells present in the brain of cyclostomes secrete a CT-like substance into the blood.

The objective of the present investigation was to examine by biochemical and biological methods whether a CT-like substance is present in the plasma of hagfish, Eptatretus burgeri.

\section{MATERIALS AND METHODS}

\section{Experimental Animals}

Eight brown hagfish, Eptatretus burgeri, caught with a trap in

Accepted July 5, 1995

Received May 8, 1995 water 10 to 50 meters deep near Misaki Marine Biological Station, University of Tokyo, on the coast of Sagami bay in November 1993 were used. Fish were anesthetized with $1 / 3000$ tricaine methanesulfonate. Thereafter, blood samples were collected from the heart with heparinized syringes, and centrifuged at $25,000 \times \mathrm{g}$ for $10 \mathrm{~min}$ at $4^{\circ} \mathrm{C}$. The plasma was immediately frozen and kept at $-50^{\circ} \mathrm{C}$ until use.

Separation of plasma by reverse-phase high-performance liquid chromatography

The plasma was acidified with glacial acetic acid to a final concentration of $1 \mathrm{M}$, vortexed and centrifuged. The high molecular weight proteins and lipids were then removed from the supernatant with $67 \%$ and $99 \%$ cold acetone, respectively. The supernatant was subjected to reverse-phase high-performance liquid chromatography (RP-HPLC) on an ODS-120T column $(4.6 \times 250 \mathrm{~mm}$, Tosoh, Tokyo) with a linear gradient from 20 to $80 \% \mathrm{CH}_{3} \mathrm{CN}$ in $0.1 \%$ trifluoroacetic acid ( $\mathrm{pH} 2.0)$

\section{Electrophoresis and Western blotting}

After RP-HPLC, $300 \mu 1$ of each fraction was lyophilized, and solubilized in lysis buffer ( $4 \% \mathrm{SDS}, 4 \%$ mercaptoethanol, $8 \mathrm{M}$ urea and $10 \mathrm{mM}$ Tris buffer adjusted with $\mathrm{HCl}$ to $\mathrm{pH} \mathrm{6.8).} \mathrm{These} \mathrm{sam-}$ ples were subjected to electrophoresis using the method of Laemmli [6] on a linear gradient gel from $10 \%$ to $20 \%$ polyacrylamide with bromophenol blue as a tracking dye. Synthetic salmon CT was used as a positive control for CT.

The samples separated by electrophoresis were transferred onto a polyvinylidene difluoride membrane (Clear blot membrane-p, Atto Co. Ltd., Tokyo) at room temperature for $2.5 \mathrm{hr}$ at $16 \mathrm{~V} / \mathrm{cm}$ according to the method of Anderson [1]. The membrane was then washed three times in phosphate buffered saline containing $0.05 \%$ Tween 20 (PBST). PBST containing 1\% normal swine serum was used to block nonspecific binding against the membrane for $15 \mathrm{~min}$ at room temperature followed by washing three times in PBST. The membrane was then incubated with polyclonal salmon CT antiserum 
(1/40000 dilution) for $12-15 \mathrm{hr}$ at room temperature. The unbound antiserum was removed by washing three times in PBST. Finally, the membrane was immunostained with a labeled streptavidin biotin kit (Dako Co. Ltd., Tokyo).

Rat bioassay

Aliquots of the fraction which showed positive immunoreactivity on Western blotting (each $300 \mu$ ) administered to 7 rats as described by Uchiyama et al. [14]. Briefly, $300 \mu$ l of each immunoreactive CT fraction was concentrated to about 10 to $20 \mu$ under vacuum, and made up to a final volume of $400 \mu \mathrm{l}$ by adding vehicle $(0.9 \%$ saline containing $0.1 \%$ bovine serum albumin, $\mathrm{pH} 4.6$ ) prior to administration. The immunonegative fraction was adopted as a control and administered to rats in the same way. Blood was sampled just before (zero) and at $0.5,1,2$, and $3 \mathrm{hr}$ after administration. Serum $\mathrm{Ca}$, inorganic phosphate $(\mathrm{Pi})$ and $\mathrm{Na}$ levels were monitored. Serum $\mathrm{Ca}$ and $\mathrm{Na}$ levels were determined with an atomic absorption spectrophotometer (180-70 type, Hitachi-Zeeman, Hitachi Co. Ltd., Tokyo). Serum Pi was measured with a spectrophotometer (100-20 type, Hitachi Co. Ltd., Tokyo) by a modification of the method of Fiske and Subbarow [3]. Student's $t$-test was applied for statistical evaluation of numerical data.

\section{Measurement of CT-like substance in plasma}

CT-like substance present in the plasma was quantified by competitive inhibition enzyme-linked immunosorbent assay (ELISA) using salmon CT antiserum, according to the procedure described by Robertson $[9,10]$. Furthermore, an ELISA system with increased sensitivity for salmon CT was developed using the streptavidin-biotin system in the present study. In this ELISA system, the detection limit was $10-30 \mathrm{pg} / \mathrm{ml}$. The specificity of anti-salmon CT antiserum was checked using synthetic peptide hormones and tissue extraction.

\section{RESULTS}

\section{Purification of CT-like substance}

The plasma was separated into twenty fractions by RP-HPLC (Fig. 1). Aliquots of $300 \mu$ l of each fraction were lyophilized and subjected to Western blotting. Two fractions (Fraction 9 eluted with $36-39 \% \mathrm{CH}_{3} \mathrm{CN}$ and fraction 10 eluted with $39-42 \% \mathrm{CH}_{3} \mathrm{CN}$ ) showed positive immunoreactivity (Fig. 2). In fraction 9, the molecular weights of the two immunopositive substances were estimated as 3.5 and 4.7 $\mathrm{kDa}$. In fraction 10 , the molecular weight (MW) of the positive substance was $4.7 \mathrm{kDa}$.

\section{Hypocalcemic activity of CT-like substance}

Changes in serum $\mathrm{Ca}$ and $\mathrm{Pi}$ levels in rats are shown in Figures 3 and 4, respectively. Administration of fraction 9 evoked significant hypocalcemia at 0.5 and $1 \mathrm{hr}$ (both $P<$ 0.05 ). Fraction 10 also induced hypocalcemia at $0.5 \mathrm{hr}$ after administration $(P<0.005)$. Only fraction 9 provoked significant hypophosphatemia at $0.5,1$ and $2 \mathrm{hr}(P<0.001, P<$ 0.005 and $P<0.05$, respectively). Serum Na levels did not change, remaining at $330 \mathrm{mg} / 100 \mathrm{ml}$ following administration of either the immunopositive or the control fraction to rats (data not shown).

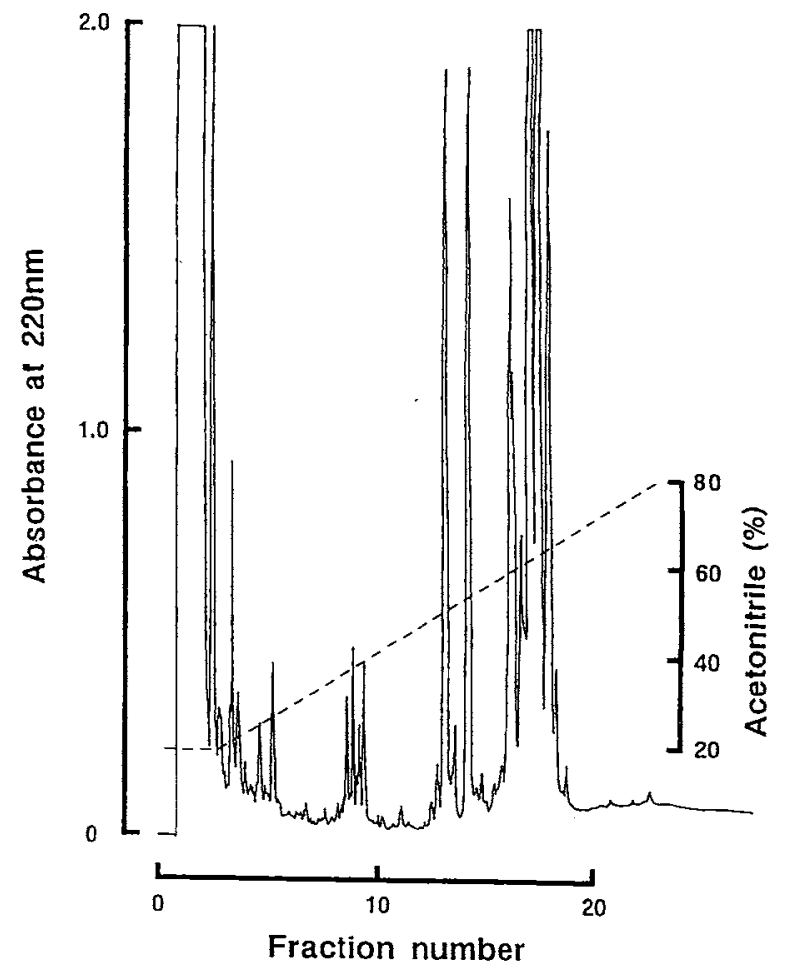

FIG. 1. Reverse-phase HPLC on an ODS-120T column. Sample: Hagfish plasma; flow rate, $1 \mathrm{ml} / \mathrm{min}$; fraction size, $3 \mathrm{ml} /$ tube. Solvent system: linear-gradient elution from $20 \%$ to $80 \%$ $\mathrm{CH}_{3} \mathrm{CN}$ in $0.1 \%$ TFA for $60 \mathrm{~min}$.

\section{T 910}

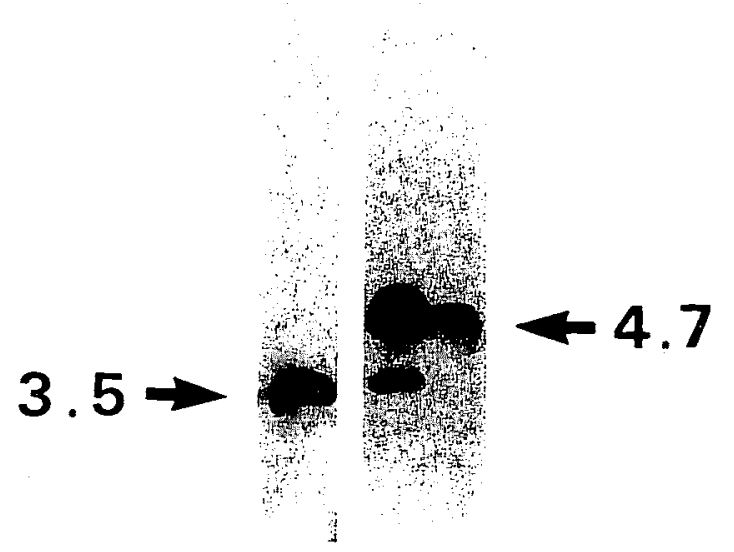

FIG. 2. Western blotting of immunoreactive calcitonin (CT) in hagfish plasma. The HPLC fractions 9 and 10 (see Fig. 1) and synthetic salmon calcitonin (sCT) as a positive control are shown. The arrows show the positions of sCT and immunoreactive $\mathrm{CT}$ with respective molecular mass in $\mathrm{kDa}$. 


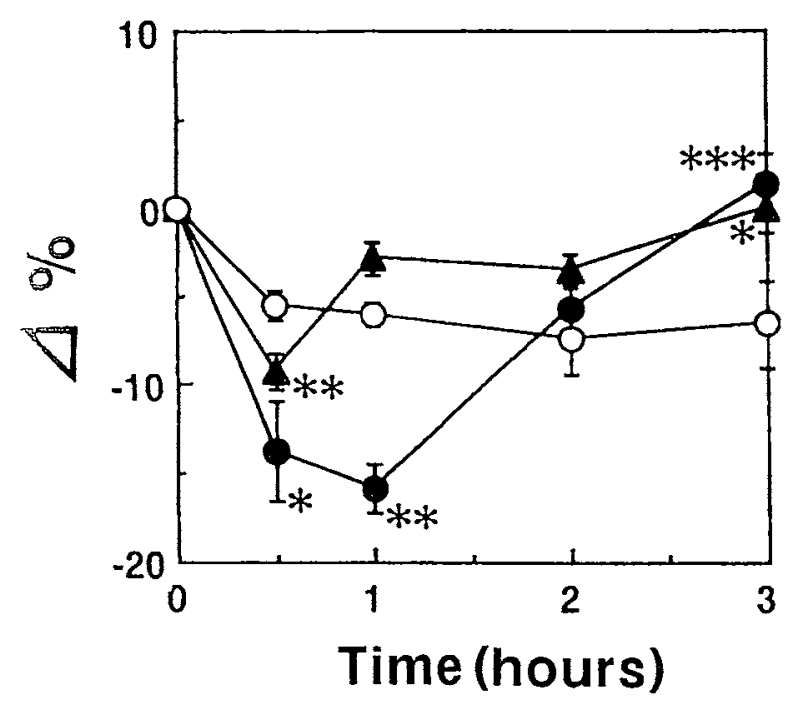

FIG. 3. Changes in serum $\mathrm{Ca}$ levels in rats after administration of fraction $9(\bullet)$, fraction $10(\Delta)$ and fraction $11(0)$ after HPLC of hagfish plasma (see Fig. 1). Vertical bars show \pm SEM. The numbers of rats used were 7 for fraction 9,7 for fraction 10 and 5 for fraction $11 .{ }^{*} P<0.05,{ }^{* *} P<0.005,{ }^{* * *} P<0.001$, compared with the values of fraction 11 .

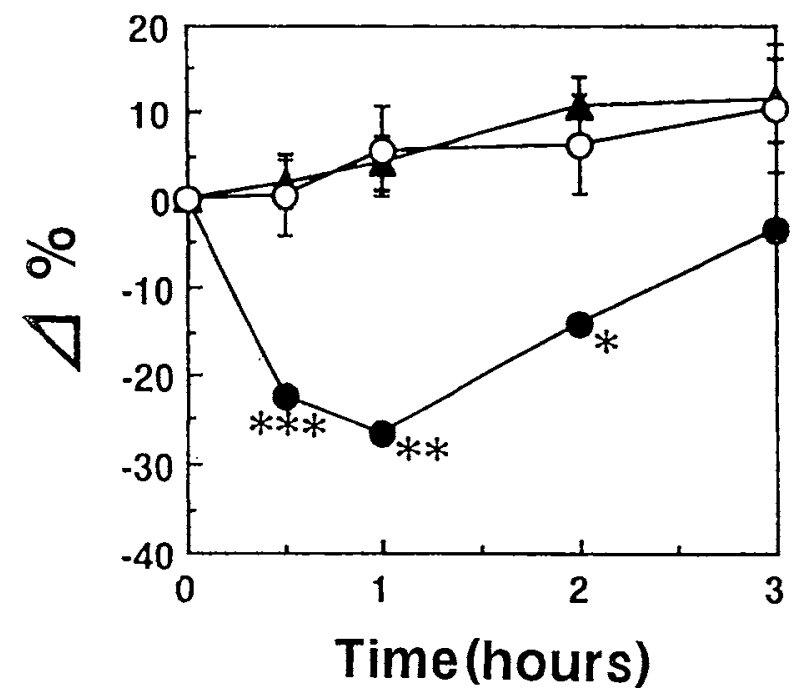

Fig. 4. Changes in serum $P i$ levels in rats after administration of fraction. $9(\bullet)$, fraction $10(\Delta)$ and fraction $11(O)$ after HPLC of hagfish plasma (see Fig. 1). Vertical bars show \pm SEM. The numbers of rats used were 7 for fraction 9,7 for fraction 10 and 5 for fraction 11. ${ }^{*} P<0.05,{ }^{* *} P<0.005,{ }^{* * *} P<0.001$, compared with the values of fraction 11 .

\section{Measurement of CT-like substance in plasma}

The level of an iCT-like substance present in the hagfish plasma was measured in an ELISA system by reactivity to anti-salmon CT serum and was calculated to be about $14 \mathrm{ng} /$ ml (Fig. 5).

\section{DISCUSSION}

In the rat bioassay, hypocalcemic activity was recognized

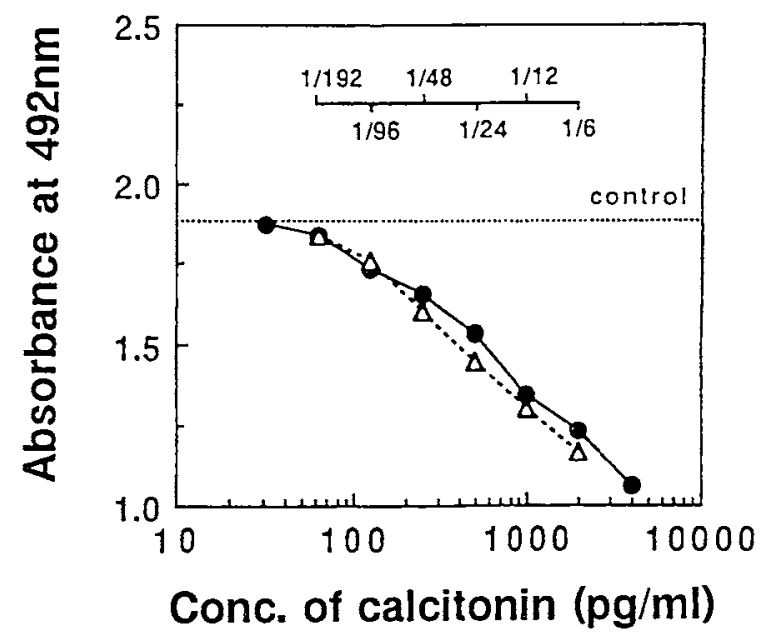

FIG. 5. Competitive inhibition curve for salmon calcitonin (sCT): and dilution curve of hagfish plasma $(\triangle)$ in the ELISA for SCT. The dilution curve paralleled the standard curve of $s C T$. The dotted line shows control with only antibody. The sample values of $\mathrm{pg} / \mathrm{ml}$ plasma were determined by multiplication of the dilution factor.

in 2 fractions of separated hagfish plasma. However, only fraction 9 showed hypophosphatemic activity. Fraction 9 contained two immunopositive substances with MW of 3.5 and $4.7 \mathrm{kDa}$, while in fraction 10 , only one CT-like substance of $4.7 \mathrm{kDa}$ was detected. However, the quantity of the 4.7 $\mathrm{kDa}$ CT-like substance in fraction 10 was less than that in fraction 9 according to the results of Western blotting (Fig. 2). Therefore, it is possible that the quantity of $4.7 \mathrm{kDa}$ was proportional to the strength of hypocalcemic activity in both fractions. On the other hand, it has been reported as a characteristic of rat bioassay that the response of serum $\mathrm{Pi}$ level to CT is larger than that of $\mathrm{Ca}[12]$. Therefore, if the $4.7 \mathrm{kDa}$ molecule included in fraction 10 is genuine $\mathrm{CT}$, the change in serum $\mathrm{Pi}$ level should be greater than that in $\mathrm{Ca}$ level on administration of fraction 10 to rats. However, the serum $\mathrm{Pi}$ level did not change. This suggests that the CT-like substance with $\mathrm{MW}$ of $3.5 \mathrm{kDa}$ possessed genuine CT-like activity. Furthermore, the concentration of CT-like substance in the hagfish plasma was estimated to be about 14 $\mathrm{ng} / \mathrm{ml}$. In teleost fish, plasma CT levels determined to date are $10-700 \mathrm{pg} / \mathrm{ml}$ in salmon [15],2000 pg/ml in eel [17] and $1500-2000 \mathrm{pg} / \mathrm{ml}$ in bass [5]. The level of CT-like substance in the plasma of hagfish was much higher than in these other fish. However, it has been reported that there are very few CT-producing cells present in the brain of hagfish [11], and it is unlikely that the CT-producing cells in the brain of hagfish can release such a large amount into the blood. Therefore, there are probably other CT-producing tissues in the hagfish in addition to the brain.

The hagfish has the highest bile $\mathrm{Ca}$ concentration determined to date among vertebrates, the level of which corresponds to 12 times that in the plasma [7]. It is known that in rats [18] and cartilaginous fish [13], CT acts on Ca excretion via bile. Therefore, the abundance of CT-like substance in 
the hagfish plasma detected here may be related to this phenomenon.

\section{ACKNOWLEDGMENTS}

The author is grateful to Professor Y. Sasayama, Noto Marine Laboratory, University of Kanazawa, for his support in experiments using the rat bioassay and to Dr. K. Inaba, Misaki Marine Biological Station, Faculty of Science, University of Tokyo, for his kind assistance in collecting cyclostomes. Particular thanks are due to Mr. C. Eguchi and Ms. A. Yoshida, Department of Biology, Faculty of Science, University of Toyama, for their assistance during the study.

\section{REFERENCES}

1 Anderson. JK (1984) Specific antiserum staining of twodimensional electrophoretic patterns of human plasma proteins immobilized on nitrocellulose. J Biochem Biophys Meth 10 : 203-209

2 Copp DH, Brooks CE, Low BS, Newsome F, O'dor RK, Parkes CO, Walker V, Watts EG (1970) Calcitonin and ultimobranchial function in lower vertebrates. In "Calcitonin" Ed by $S$ Taylor, Heinemann, London, pp 281-294

3 Fiske CH, Subbarow Y (1925) The colorimetoric determination of phosphorus. J Biol Chem 66: 375-400

4 Girgis SL, Galan Galan F, Arnett TR, Rogers RM, Bone Q, Ravazzola M, MacIntyre I (1980) Immunoreactive human calcitonin-like molecule in the nervous systems of protochordates and a cyclostome, Myxine. J Endocrinol 87: 375-382

5 Glowacki J, O'sullivan J, Miller M, Wilkie DW, Deftos LJ (1985) Calcitonin produces hypocalcemia in leopard sharks. Endocrinology 116: 827-829

6 Laemmli UK (1970) Cleavage of structural proteins during the assembly of the head of bacteriophage T4. Nature 227: 680685
7 Morris. R (1965) Studies on the salt and water balance in Myxine glutinosa (L.). J Exp Biol 42: 359-371

8 Reginster JY (1993) Calcitonin for prevention and treatment of osteoporosis. Am J Med 95 (Suppl 5A): 44-47

9 Robertson DR (1981) A competitive inhibition enzyme-linked immunosorbent assay for frog calcitonin. Gen Comp Endocrinol 45: $12-20$

1010 Robertson DR (1986) Calcitonin. In "Methods of Enzymatic Analysis Vol IX" Ed by HU Bergmeyer, Verlag-Chemie Weinheim, Verlagsgesellschaft, pp 497-508

11 Sasayama Y, Koizumi T, Oguro C, Kambegawa A, Yoshizawa $H$ (1991) Calcitonin-immunoreactive cells are present in the brains of some cyclostomes. Gen Comp Endocrinol 84: 284290

12 Sasayama Y, Suzuki N, Oguro C, Takei Y, Takahashi A, Watanabe TX, Nakajima K, Sakakibara S (1992) Calcitonin of the stingray: comparison of the hypocalcemic activity with other calcitonins. Gen Comp Endocrinol 86: 269-274

13 Suźuki N, Takagi T, Sasayama Y, Kambegawa A (1995) Effects of ultimobranchialectomy on the mineral balances of the plasma and bile in the stingray (Elasmobranchii). Zool Sci 12: 239-242

14 Uchiyama M, Yoshihara M, Murakami T, Oguro C (1978) Presence of a hypocalcemic factor in the ultimobranchial gland of the snake. Gen Comp Endocrinol 36: 59-62

15 Watts EG, Coop DH, Deftos LJ (1975) Changes in plasma calcitonin and calcium during the migration of salmon. Endocrinology 96: $214-218$

16 Watzka M (1933) Vergleichende Untersuchungen über den ultimo-branchialen Körper, Z Mikrosk Anat Forsch 34: 485-533

17 Yamauchi $\mathrm{H}$, Orimo $\mathrm{H}$, Yamauchi $\mathrm{K}$, Takano $\mathrm{K}$, Takahashi $\mathrm{H}$ (1978) Increased calcitonin levels during ovarian development in the eel, Anguilla japonica. Gen Comp Endocrinol 36: 526529

18 Yamaguchi M, Yamamoto T (1979) Effects of various calcitonins on calcium concentrations in the bile and serum of thyroparathyroidectomized rats. Chem Pharm Bull 27: 1671-1674 